\title{
Penerapan Estimasi Posisi dan Tracking Wajah Pada Sistem Presensi Mahasiswa
}

\author{
http://dx.doi.org/10.28932/jutisi.v6i2.2730
}

\author{
Afrillebar Putra Pratama ${ }^{\bowtie \# 1}$, Agi Prasetiadi ${ }^{* 2}$, Elisa Usada ${ }^{\# 3}$ \\ \# Jurusan S1 Teknik Informatika, Institut Teknologi Telkom Purwokerto \\ Jl. DI Panjaitan No.128, Pancurawis, Purwokerto Kidul, Kec. Purwokerto Sel., Kabupaten Banyumas, Jawa Tengah

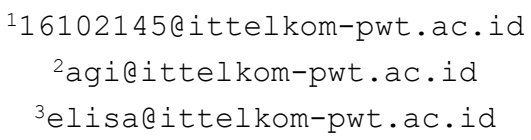

\begin{abstract}
The current presence system can be done with a computerized system, one of which is the face biometric system. This study focuses on the application of position estimation and tracking based on clustering on people's faces to determine the position in three dimensions. Position estimation can be obtained by making a kernel that is ready to be used to predict three-dimensional coordinates of faces based on two-dimensional coordinates of two images. Position estimation can be done by utilizing the Machine Learning algorithm family. In this study, Least Absolute Shrinkage and Selection Operators (LASSO) is used to perform the position estimation. Meanwhile, clustering in this study uses the $\mathrm{K}$ Means algorithm. Based on the test results, the kernel error obtained in estimating the face location is $9.23 \mathrm{~cm}$. The tracking accuracy of an object based on clustering is $100 \%$.
\end{abstract}

Keywords - K-Means; LASSO; Machine Learning; Object Tracking; Position Estimation.

\section{Pendahuluan}

Sistem presensi berdasarkan cara penggunaannya ada dua, yaitu manual dan non-manual. Presensi manual dilakukan dengan tanda tangan di buku kehadiran. Sedangkan non-manual dilakukan dengan alat yang sudah terkomputerisasi [1].

Presensi manual memiliki banyak kelemahan seperti terjadinya tindak kecurangan oleh mahasiswa dengan memalsukan tanda tangan serta dapat terjadi akibat human error ketika staff kampus memasukkan data ke database. Saat ini, presensi manual dapat digantikan dengan sistem yang sudah terkomputerisasi yaitu dengan sistem biometrik contohnya sidik jari, suara, wajah, dan lain-lain [2].

Perkembangan sistem presensi saat ini sudah mulai merambah melalui identifikasi wajah yang dilakukan oleh kamera di dalam ruangan yang berfungsi untuk mengidentifikasi dan mengetahui posisi wajah [3]. Pemanfaatan kamera digital dilakukan untuk mengetahui estimasi posisi atau menentukan letak lokasi suatu objek dalam suatu ruang yang terjangkau pandangan kamera sehingga dapat mengenali koordinat lokasi objek [4].

Estimasi posisi dengan pendekatan ciri visual pada umumnya dapat dilakukan dengan dua kamera (stereoskopik) atau kamera 3D yang sudah dilengkapi dengan sensor kedalaman. Teknik-teknik tersebut membutuhkan sensor yang lebih banyak sehingga harga perangkat keras untuk aplikasi menjadi lebih mahal [5]. Sebagai alternatifnya, penelitian ini menggunakan dua kamera smartphone dengan meniru cara kerja dari mata manusia yang memiliki dua sudut pandang berbeda. Kamera smartphone tersebut digunakan sebagai masukkan citra untuk menghasilkan citra digital yang kemudian diolah dengan model Machine Learning untuk memprediksi lokasi dalam bentuk koordinat 3D dan dapat membedakan orang satu dengan orang lainnya.

Penelitian ini mengacu pada penelitian sebelumnya yang bertujuan merancang simulasi penentuan koordinat objek di dalam ruang menggunakan kamera digital. Penelitian tersebut menerapkan pendekatan proyeksi perspektif hasil kamera yang dapat dirumuskan secara matematis menggunakan dua titik hilang dengan empat titik acuan menggunakan objek berupa pola ubin berukuran $40,25 \times 40,25 \mathrm{~cm}$. Penggunaan metode ini memperoleh tingkat presisi mencapai $2,71 \mathrm{~cm} \mathrm{[4].}$

Berdasarkan acuan penelitian tersebut, penelitian ini melakukan alternatif pemodelan lain untuk memprediksi lokasi wajah dalam bentuk koordinat 3D menggunakan algoritma Least Absolute Shrinkage and Selection Operator (LASSO) dan melakukan tracking berbasis clustering untuk melacak tiap-tiap wajah dengan algoritma $K$-Means. Kedua algoritma tersebut dijalankan dengan memanfaatkan ScikitLearn Library. Hasil dari estimasi posisi dan clustering kemudian di plotting ke dalam 3D Scatter Plot dengan memanfaatkan Matplotlib Library. Dengan menggabungkan kedua fungsi tersebut, model ini dapat digunakan sebagai penunjang sistem presensi yang dibangun menggunakan Tkinter GUI sehingga dapat memberikan informasi baru berupa lokasi wajah sebagai alternatif model. 


\section{LANDASAN TEORI}

\section{A. Presensi}

Presensi merupakan tindakan pendataan kehadiran sebagai aktifitas pelaporan di sebuah institusi yang telah tersusun rapi sehingga mudah dicari dan digunakan kembali saat diperlukan. Di dunia perkuliahan, presensi menjadi salah satu aspek bagi dosen dalam menentukan nilai akhir mahasiswa [1].

\section{B. Estimasi Posisi}

Estimasi posisi adalah proses melakukan estimasi terhadap posisi objek pada koordinat nyata berdasarkan koordinat objek pada video. Estimasi posisi dilakukan agar informasi mengenai pergerakan objek dapat dimengerti oleh manusia karena menggunakan koordinat dunia nyata [6].

Salah satu sistem koordinat yang terkenal adalah sistem koordinat kartesian. Sistem koordinat kartesian pada dasarnya terdiri dari sistem koordinat kartesian 2D dan 3D. Perbedaanya pada sistem koordinat 3D terdapat sumbu selain $x$ dan $y$, yaitu sumbu $z$ yang arahnya tegak lurus terhadap sumbu $x$ dan $y$ [7].

\section{Citra Digital}

Citra merupakan representasi 2D dari bentuk fisik nyata 3D. Citra digital merupakan citra 2D yang dapat ditampilkan pada layar komputer dalam bentuk piksel. Posisi koordinat pada bidang citra di layar mengacu pada sistem koordinat kartesian dengan sumbu mendatar dinyatakan dengan sumbu $x$, dan sumbu tegak dinyatakan dengan sumbu $y[8]$.

\section{Pengenalan Wajah}

Sistem pengenalan wajah bekerja dengan cara mengambil data wajah digital dari sebuah citra atau frame pada video dan membandingkannya dengan data wajah yang tersimpan di database. Sistem pengenalan wajah yang ada harus mampu membedakan wajah dengan latar belakang citra agar dapat mengenali wajah manusia atau bukan [9].

\section{E. OpenCV}

OpenCV (Open Computer Vision Library) merupakan open source library yang memiliki lebih dari 500 algoritma dan telah dioptimasi serta disediakan untuk menangani permasalahan mengenai computer vision dan machine learning [3].

\section{F. Machine Learning}

Machine learning biasa digunakan untuk menirukan perilaku manusia dalam menyelesaikan suatu masalah atau melakukan otomatisasi dan ciri khasnya adalah proses pelatihan dan pembelajaran [10].

\section{G. LASSO}

LASSO merupakan salah satu metode machine learning yang cocok diterapkan pada data non-linear yang bersifat polynomial dan mengandung multikolinieritas karena antara satu variabel atau lebih dengan variabel lainnya memiliki hubungan yang kuat. LASSO mengurangi sejumlah koefisien ke arah nol bahkan tepat nol sehingga model yang dihasilkan menjadi lebih sederhana dan terhindar dari multikolinieritas [11]. Algoritma LASSO ini digunakan untuk memprediksi koordinat 3D $(x, y, z)$ berdasarkan masukkan koordinat 2D dari dua kamera $(x 1, y 1, x 2, y 2)$.

\section{H. K-Means}

Klasterisasi yang ada pada K-Means dilakukan dengan cara memisahkan data ke dalam kelompok yang berbeda atau biasa disebut dengan cara partitioning. Cara ini mampu meminimalkan rata-rata jarak setiap data ke klasternya dan mampu melakukan komputasi lebih cepat dari pengelompokan hirarkis [12]. Berikut tahapan K-Means:

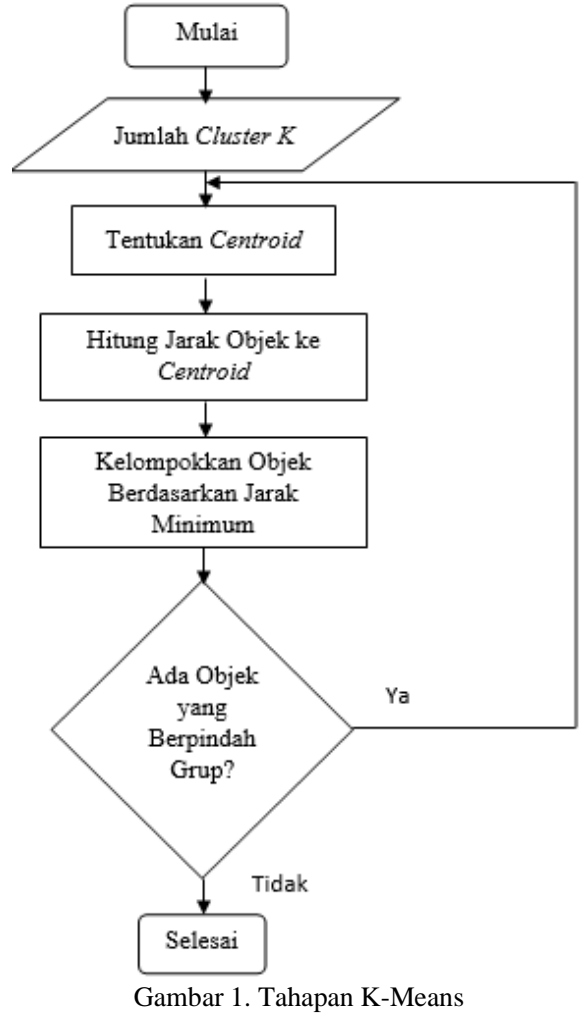

$K$-Means digunakan untuk mengelompokkan data piksel 2D berdasarkan jumlah orang. Jumlah dari data tersebut tergantung pada hasil tangkapan setiap frame pada durasi video yang telah ditentukan. Berdasarkan Gambar 1 dapat dijelaskan bahwa tahapan $K$-Means yaitu:

1. Tentukan nilai $k$ sebagai jumlah klaster

Jumlah klaster tergantung pada jumlah orang yang ada di video demo yang digunakan sebagai data uji. Jika terdapat satu orang, maka jumlah klasternya adalah satu. Jika dua orang, maka jumlah klasternya dua dan begitu seterusnya.

2. Inisialiasasi $k$ centroid awal secara acak Setelah jumlah klaster ditentukan, selanjutnya menginisialisasi centroid secara acak sehingga didapatkan nilai tengah dari klaster yang akan dibentuk. 
3. Hitung jarak objek ke centroid

Langkah ini dilakukan untuk mengelompokkan setiap data yang berada di jarak terdekat berdasarkan jumlah klaster. Penghitungan jarak yang digunakan pada penelitian ini yaitu menggunakan Euclidean Distance.

4. Tempatkan setiap data ke klaster terdekat

Tahap selanjutnya setelah perhitungan jarak objek ke centroid adalah dengan menempatkan setiap data atau objek berdasarkan jarak terdekat. Pada langkah ini data-data akan dikelompokkan menjadi beberapa kelompok sesuai dengan jumlah klaster yang telah ditentukan.

5. Pilih kembali centroid untuk tiap-tiap klaster Apabila pengelompokkan telah dilakukan, selanjutnya pilih kembali centroid untuk tiap-tiap klaster dengan tujuan mengetahui apakah masih ada data yang berpindah kelompok atau tidak. Jika sudah tidak ada lagi yang berpindah kelompok, maka clustering telah selesai dilakukan. Namun, jika masih terdapat perpindahan kelompok maka kembali ke langkah dua hingga tidak ada lagi data yang berpindah kelompok.

\section{METOdOLOGI PENELITIAN}

Pada penelitian ini terdapat tiga tahapan penelitian yang digambarkan pada Gambar 2.

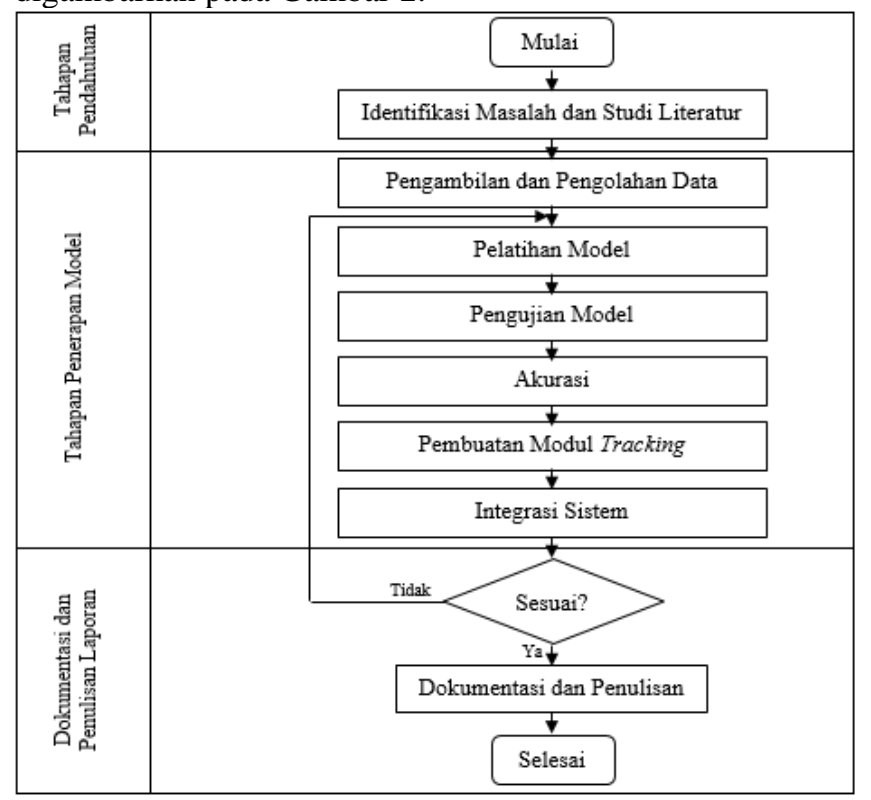

Gambar 2. Metodologi Penelitian

\section{A. Identifikasi Masalah dan Studi Literatur}

Identifikasi masalah yang dilakukan pada penelitian ini dengan cara observasi mengenai presensi yang tengah berjalan karena masih memerlukan campur tangan manusia. Permasalahan ini yang diangkat menjadi topik penelitian karena presensi bisa dilakukan secara otomatis dengan sistem biometrik wajah dan diketahui posisi untuk tiap-tiap orangnya. Sedangkan studi literatur yang dilakukan dengan membaca jurnal relevan.

\section{B. Pengambilan dan Pengolahan Data}

Tahapan pengambilan dan pengolahan data pada penelitian ini digambarkan melalui Gambar 3.

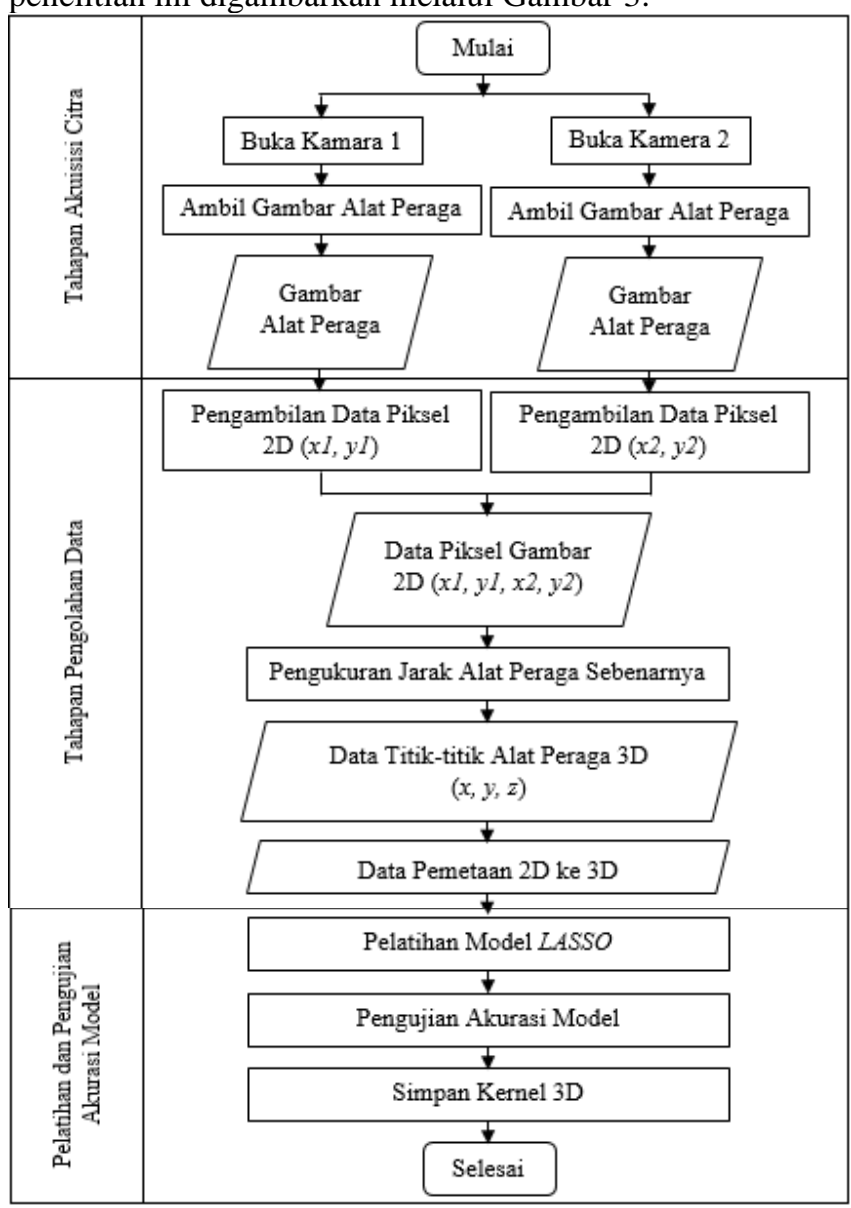

Gambar 3. Pengambilan dan Pengolahan Data

Berdasarkan Gambar 3 data diperoleh dari hasil pengambilan gambar alat peraga menggunakan dua kamera. Gambar kedua alat peraga tersebut kemudian ditentukan piksel 2D-nya lalu digabungkan sehingga menghasilkan data piksel gambar 2D $(x 1, y 1, x 2, y 2)$. Langkah selanjutnya yaitu pengukuran jarak dari alat peraga yang sebenarnya. Pengukuran jarak ini dilakukan dengan mengukur panjang antara titik tengah alat peraga yang menyerupai koordinat kartesian 3D dengan ketiga sumbunya $(x, y, z)$.

Apabila pengukuran jarak alat peraga sudah didapatkan, kemudian digabungkan dengan gambar 2D sehingga dihasilkan data pemetaan 2D dan 3D. Data inilah yang dijadikan sebagai data latih dan akan dieksekusi menggunakan model LASSO. Selanjutnya dilakukan pengujian akurasi menggunakan Mean Absolute Error $(M A E)$. Hasil dari pelatihan tersebut kemudian disimpan dengan memanfaatkan Pickle Library yang banyak digunakan untuk menyimpan model Machine Learning. Data dalam penyimpanan Pickle ini kemudian di load untuk memprediksi koordinat 3D berdasarkan masukkan piksel 2D dari data uji yang berupa titik tengah pada wajah manusia. 


\section{Pengujian Model}

Tahapan pengujian model pada penelitian ini digambarkan pada Gambar 4.

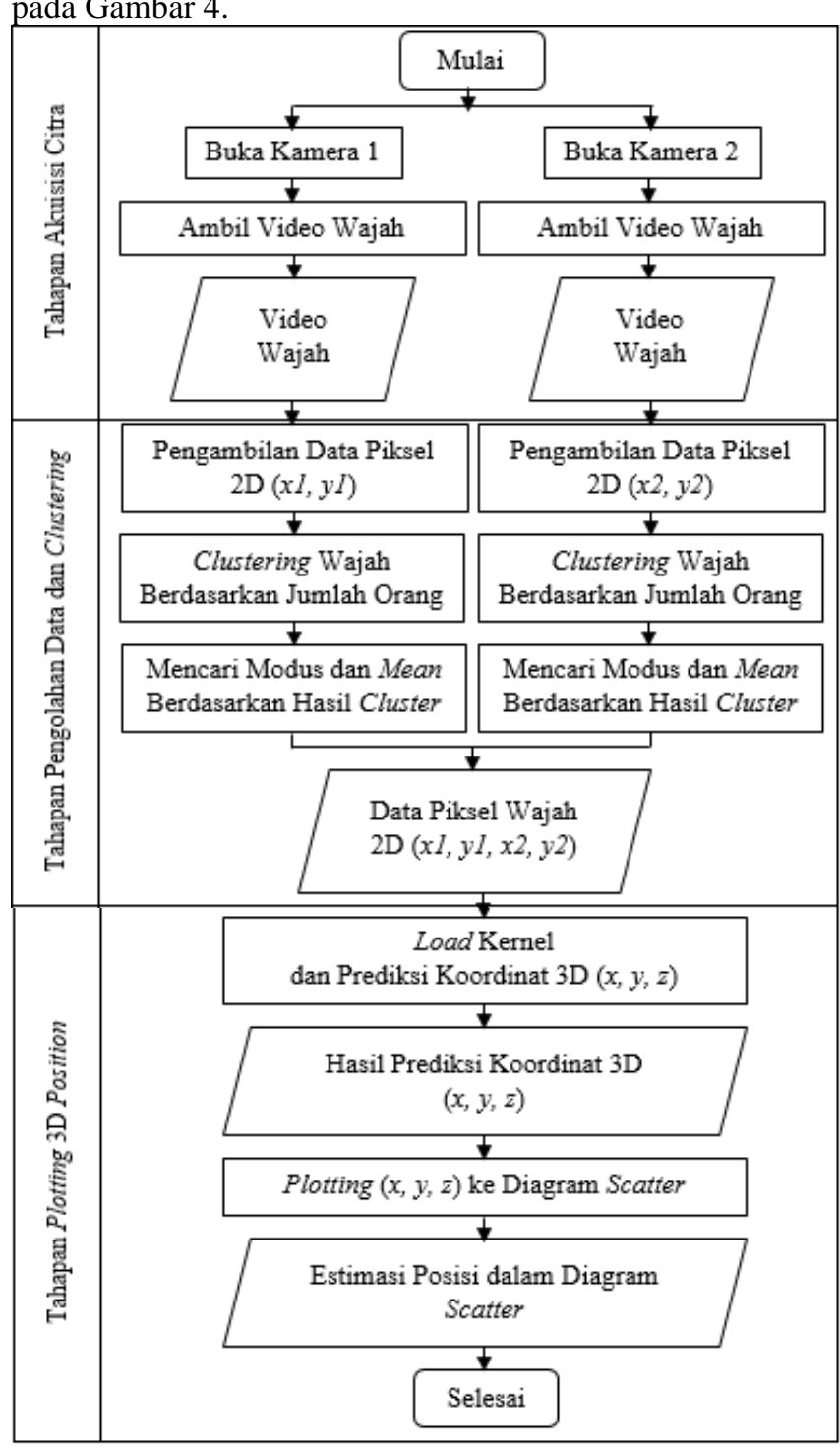

Gambar 4. Pengujian Model

Gambar 4 merupakan tahapan pengujian model dimana data uji yang digunakan adalah data baru berupa koordinat dari citra wajah pada layar komputer. Koordinat tersebut didapatkan dari titik tengah piksel pada bounding box citra wajah yang telah terdeteksi. Selanjutnya dilakukan tracking berbasis clustering berdasarkan jumlah orang yang ada untuk tiap-tiap video yang diambil dari dua kamera berbeda, kemudian dicari modus untuk memastikan kebenaran setiap orang dari clustering yang telah dilakukan.

Langkah selanjutnya yaitu mencari mean berdasarkan pergerakan setiap orang yang ada pada video. Penggunaan mean ini bertujuan untuk mengetahui lokasi orang yang ada pada video karena pada dasarnya setiap mahasiswa tidak banyak bergerak ketika kegiatan belajar mengajar berlangsung.
Hasil clustering untuk tiap-tiap video dari dua kamera yang berbeda tersebut kemudian digabungkan sehingga didapatkan data piksel wajah 2D. Data piksel wajah 2D inilah yang akan diprediksi koordinat 3D-nya. Hasil prediksi tersebut kemudian di plotting ke dalam 3D Scatter Plot.

\section{Pengembangan Sistem}

Metode yang diterapkan dalam membangun perangkat lunak yaitu menggunakan SDLC. Berikut tahapan metode pada SDLC:

1) Tahap Perencanaan: Tahap awal ini menjelaskan identifikasi masalah, pengumpulan data, dan studi literatur yang bertujuan agar permasalahan yang akan diteliti dapat teridentifikasi dengan jelas.

2) Tahap Analisis Kebutuhan: Tahapan ini dilaksanakan untuk mengidentifikasi beberapa kebutuhan dasar dari sistem serta mempelajari teknik-teknik yang diperlukan untuk pengembangan sistem.

3) Tahap Perancangan: Tahap ini menggunakan Unified Modeling Language (UML) untuk membuat gambaran umum dan alur logika sistem.

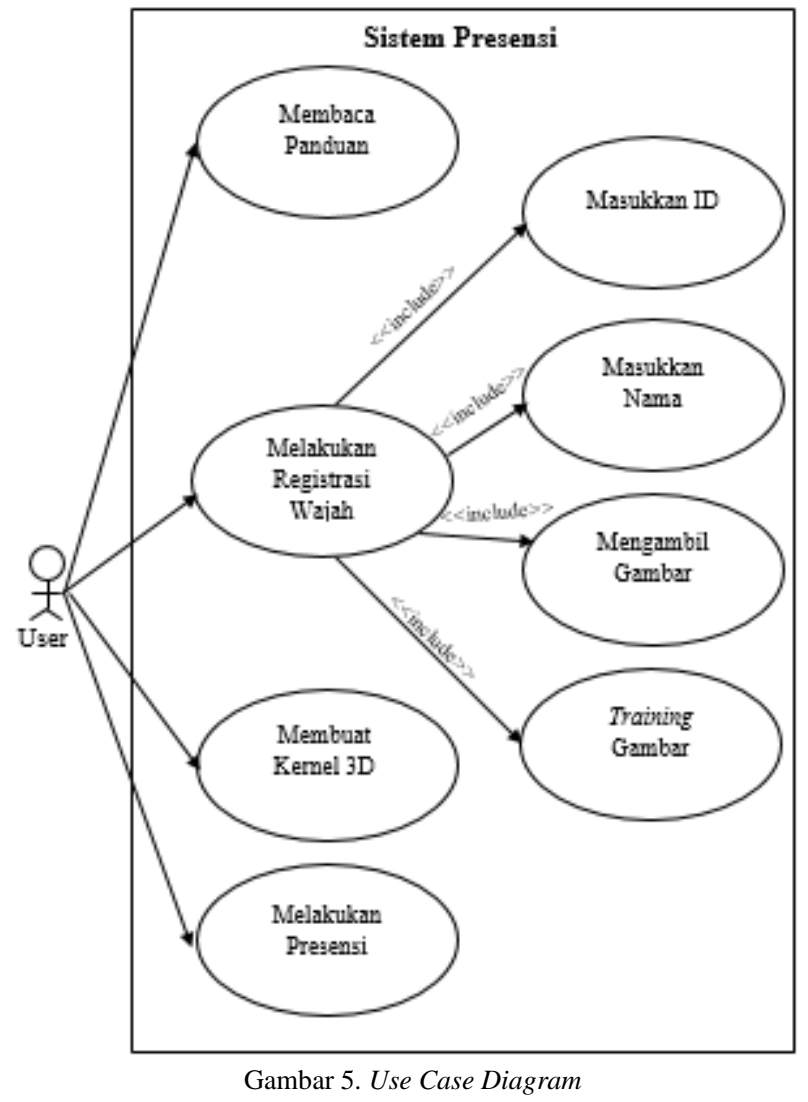

Gambar 5 merupakan aksi yang dilakukan user untuk dapat melakukan presensi pada sistem yang dibuat. User dapat membaca panduan untuk mengetahui panduan dalam menjalankan sistem, user juga dapat melakukan registrasi wajah baru dengan cara memasukkan ID, dan nama 
kemudian diambil gambarnya untuk memperoleh dataset dan di training. Adapun Activity Diagram dari Use Case dapat dilihat pada Gambar 6, Gambar 7, Gambar 8, dan Gambar 9.

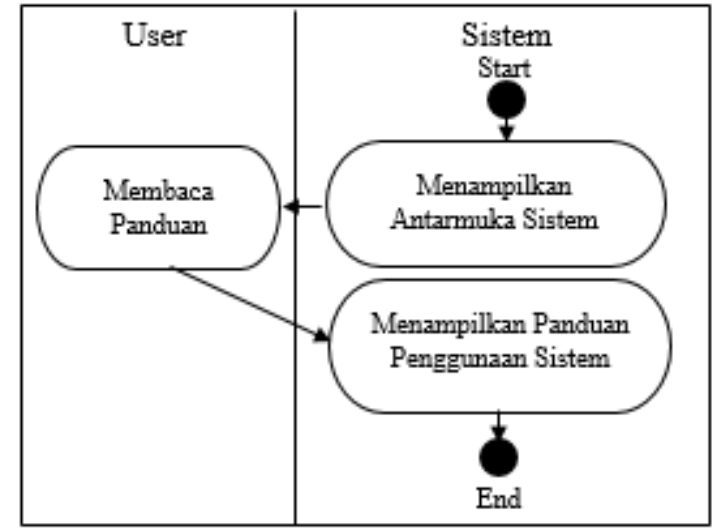

Gambar 6. Activity Diagram: Membaca Panduan

Gambar 6 menjelaskan bahwa user dapat mengetahui alur kerja dari sistem dengan cara membaca panduan yang ada di antarmuka sistem. Panduan tersebut berisi alur kerja bagaimana presensi dapat dilakukan dengan baik pada sistem tersebut.

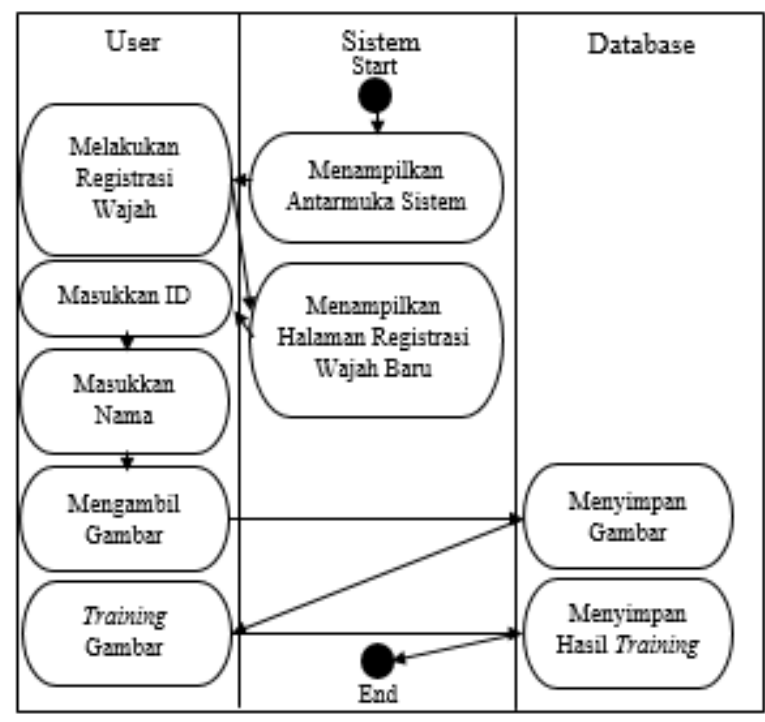

Gambar 7. Activity Diagram: Melakukan Registrasi Wajah

Gambar 7 menjelaskan mengenai tahapan yang harus dilalui user untuk melakukan registrasi wajah baru hingga dihasilkan data training agar dapat dilakukan identifikasi atau pengenalan wajah. User dapat melakukan registrasi wajah dengan memasukkan ID dan nama terlebih dahulu sebagai identitas dari orang tersebut, kemudian dilakukan proses pengambilan gambar untuk dataset wajah menggunakan Haar Cascade Classifier dan di training dengan LBPH.

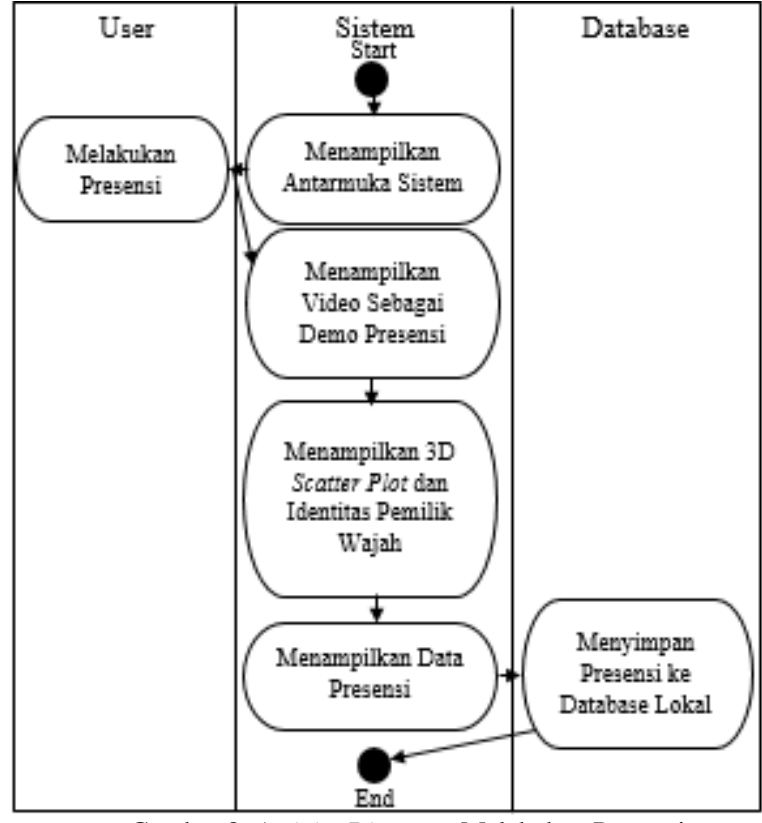

Gambar 8. Activity Diagram: Melakukan Presensi

Gambar 8 menjelaskan bahwa presensi dapat dilakukan menggunakan video demo yang telah dibuat sebelumnya dan berisi beberapa orang sebagai simulasi presensi. Hasil akhir dari presensi ini akan menampilkan mapping berdasarkan estimasi posisi untuk setiap orang yang telah terdeteksi dan menampilkan data presensi.

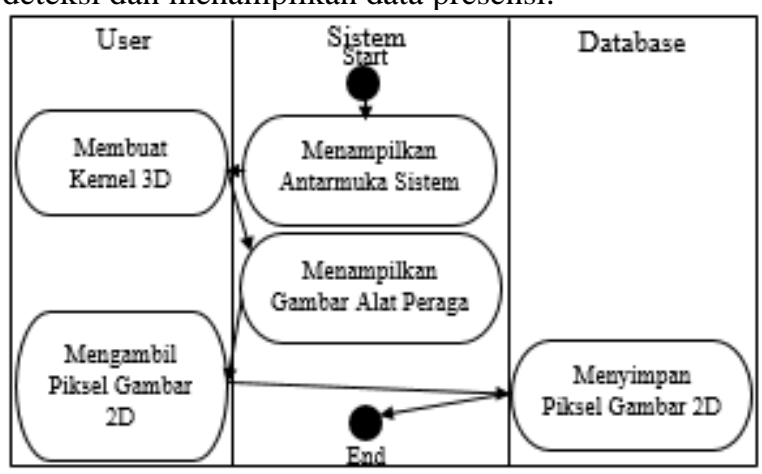

Gambar 9. Activity Diagram: Membuat Kernel 3D

Gambar 9 menjelaskan mengenai pembuatan kernel 3D yang perlu dilakukan terlebih dahulu sebelum presensi. Hal ini diperlukan untuk mengetahui posisi dari setiap orang yang terdeteksi. Pembuatan kernel ini dilakukan menggunakan algoritma LASSO. Piksel 2D dari gambar alat peraga diperoleh dari program Mouse Event Click Python.

4) Tahap Implementasi: Tahap ini sistem mulai dibangun sesuai analisis kebutuhan dan perancangan yang telah dibuat. Penelitian ini menggunakan perangkat keras Laptop Asus A455L untuk mengimplementasikan sistem. Sedangkan untuk proses pengambilan citra digital menggunakan kamera smartphone Samsung Galaxy A50, dan Vivo v91. Sedangkan untuk membuat program Python menggunakan Visual Studio Code sebagai perangkat lunak. 
5) Tahap Pengujian: Di tahap ini sistem dilakukan pengujian terhadap hasil dari implementasi yang telah dibuat. Ada lima pengujian yang ada pada penelitian ini yaitu pengujian pada kernel yang digunakan untuk memprediksi lokasi wajah, pengujian estimasi posisi untuk mengukur keakuratan posisi asli dan prediksi, pengujian pengenalan wajah, pengujian clustering untuk mengukur ketapatan hasil cluster terhadap beberapa wajah, dan pengujian sistem untuk mengetahui keseluruhan sistem berjalan dengan baik atau tidak.

\section{HASIL PENGUJIAN DAN ANALISIS}

\section{A. Pengujian Kernel LASSO}
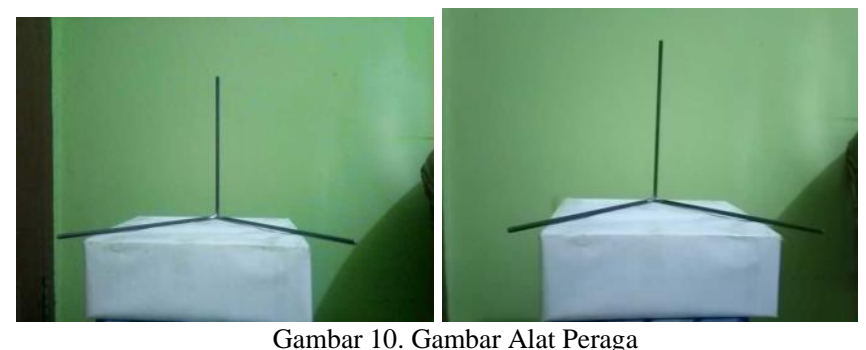

Gambar 10 merupakan gambar alat peraga yang digunakan dalam pembuatan kernel karena menyerupai sistem koordinat kartesius 3D. Data yang diambil berupa piksel 2D dengan program Mouse Event Click pada Opencv Library. Alat peraga tersebut diletakkan di lokasi tempat pengujian bersamaan dengan pengambilan video demo.

Data piksel 2D diambil dengan melakukan klik pada titik tengah, ujung kiri, ujung kanan, dan ujung atas secara bergantian dari dua gambar alat peraga berdasarkan dua kamera berbeda yang digunakan sebagai empat titik acuan. Tabel I dan Tabel II merupakan data dari piksel 2D.

TABEL I

PIKSEL GAMBAR KAMERA 1

\begin{tabular}{|c|c|}
\hline $\mathbf{x 1}$ & $\mathbf{y 1}$ \\
\hline 294,0 & 264,0 \\
\hline 130,0 & 260,0 \\
\hline 434,0 & 259,0 \\
\hline 296,0 & 102,0 \\
\hline
\end{tabular}

Tabel I merupakan data piksel 2D yang diperoleh dari gambar alat peraga kamera 1 .

TABEL II

PIKSEL GAMBAR KAMERA 2

\begin{tabular}{|c|c|}
\hline $\mathbf{x 2}$ & $\mathbf{y 2}$ \\
\hline 308,0 & 262,0 \\
\hline 151,0 & 258,0 \\
\hline 450,0 & 263,0 \\
\hline 310,0 & 104,0 \\
\hline
\end{tabular}

Tabel II merupakan data piksel 2D yang diperoleh dari gambar alat peraga kamera 2. Data pada Tabel I, dan Tabel II kemudian diolah dengan menambahkan titik-titik antara titik tengah dengan tiap-tiap ujung dan antara ujung satu dengan ujung lainnya sehingga mendapatkan 10 titik gambar pada objek. Apabila digambarkan dalam bangun 3D adalah sebagai berikut:

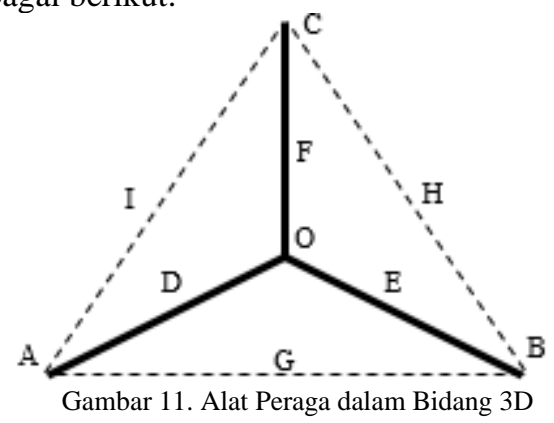

Keterangan:

Titik $\mathrm{O}=0 \mathrm{~cm}$

Titik A, B, C $=30 \mathrm{~cm}$

Titik D, E, F, G, H, I = $15 \mathrm{~cm}$

Gambar 11 menggambarkan pengukuran jarak alat peraga yang sebenarnya. Kemudian hasil pengukuran tersebut dituangkan pada Tabel III yang merupakan pemetaan 2D dan 3D yang berasal dari gambar objek pada layar sebagai piksel 2D dan besaran objek sesungguhnya di dunia nyata.

TABEL III

PEMETAAN 2D DAN 3D

\begin{tabular}{|c|c|c|c|c|c|c|}
\hline $\mathbf{x 1}$ & $\mathbf{y 1}$ & $\mathbf{x 2}$ & $\mathbf{y 2}$ & $\mathbf{x}$ & $\mathbf{y}$ & $\mathbf{z}$ \\
\hline 294,0 & 264,0 & 308,0 & 262,0 & 0,0 & 0,0 & 0,0 \\
\hline 130,0 & 260,0 & 151,0 & 258,0 & 30,0 & 0,0 & 0,0 \\
\hline 434,0 & 259,0 & 450,0 & 263,0 & 0,0 & 30,0 & 0,0 \\
\hline 296,0 & 102,0 & 310,0 & 104,0 & 0,0 & 0,0 & 30,0 \\
\hline 212,0 & 262,0 & 229,5 & 260,0 & 15,0 & 0,0 & 0,0 \\
\hline 364,0 & 261,5 & 379,0 & 262,5 & 0,0 & 15,0 & 0,0 \\
\hline 295,0 & 183,0 & 309,0 & 183,0 & 0,0 & 0,0 & 15,0 \\
\hline 282,0 & 259,5 & 300,5 & 260,5 & 15,0 & 15,0 & 0,0 \\
\hline 365,0 & 180,5 & 380,0 & 183,5 & 0,0 & 15,0 & 15,0 \\
\hline 213,0 & 181,0 & 230,5 & 181,0 & 15,0 & 0,0 & 15,0 \\
\hline
\end{tabular}

Tabel III merupakan data pemetaan 2D dan 3D yang digunakan untuk data training dalam pembuatan kernel 3D. Pembuatan kernel hanya dilakukan sekali ketika letak kamera berada di lokasi yang sama, namun jika lokasi berbeda maka perlu membuat ulang kernel sesuai lokasi yang digunakan agar posisi objek dapat diketahui dengan akurat. Berdasarkan data tersebut, kemudian dilakukan pelatihan menggunakan algoritma LASSO. Penerapan algoritma $L A S S O$ akan dijelaskan pada kode program 1 berdasarkan dataset yang ada pada Tabel III.

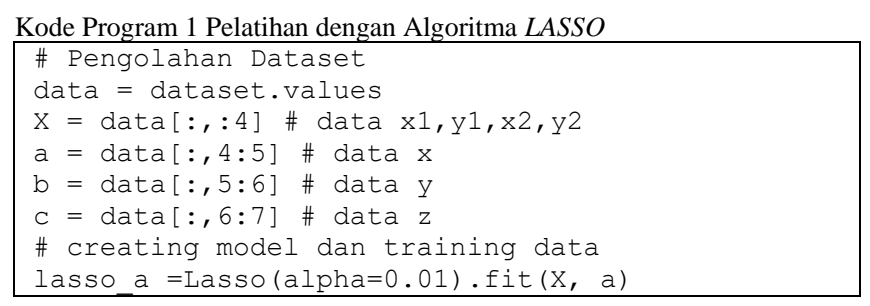




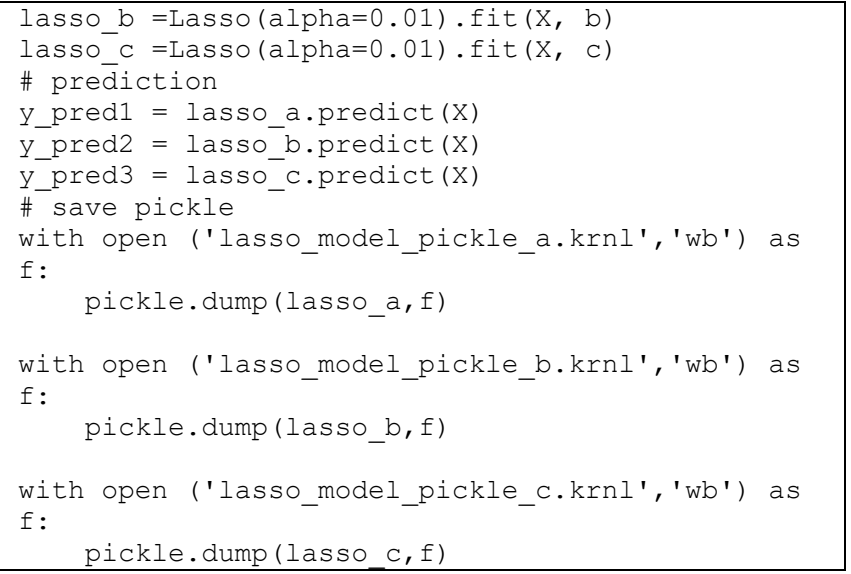

Hasil perbandingan antara koordinat asli dan prediksi 3D pada koordinat $x, y$, dan $z$ dapat dlihat pada Tabel IV, Tabel $\mathrm{V}$, dan Tabel VI.

TABEL IV

Perbandingan Koordinat AsLi Dan PRediksi Koordinat X

\begin{tabular}{|c|c|c|c|}
\hline No & Asli & Prediksi & Error $(\mathbf{c m})$ \\
\hline 1 & 0 & 4,96 & 4,96 \\
\hline 2 & 30 & 27,62 & 2,38 \\
\hline 3 & 0 & $-2,63$ & 2,63 \\
\hline 4 & 0 & 0,04 & 0,04 \\
\hline 5 & 15 & 16,29 & 1,29 \\
\hline 6 & 0 & 1,17 & 1,17 \\
\hline 7 & 0 & 2,50 & 2,50 \\
\hline 8 & 15 & 12,50 & 2,50 \\
\hline 9 & 0 & $-1,29$ & 1,29 \\
\hline 10 & 15 & 13,83 & 1,17 \\
\hline \multicolumn{4}{|c|}{ MAE } \\
\hline
\end{tabular}

Berdasarkan Tabel IV didapatkan error berdasarkan perhitungan $M A E$ koordinat $x$ sebesar $1,99 \mathrm{~cm}$, di mana error terbesar yaitu $4,96 \mathrm{~cm}$ dan terkecil sebesar $0,04 \mathrm{~cm}$.

TABEL V

PERBANDINGAN KOORDINAT ASLI DAN PREDIKSI KOORDINAT Y

\begin{tabular}{|c|c|c|c|}
\hline No & Asli & Prediksi & Error $(\mathbf{c m})$ \\
\hline 1 & 0 & 5,81 & 5,81 \\
\hline 2 & 0 & $-2,78$ & 2,78 \\
\hline 3 & 30 & 26,92 & 3,08 \\
\hline 4 & 0 & 0,05 & 0,05 \\
\hline 5 & 0 & 1,51 & 1,51 \\
\hline 6 & 15 & 16,37 & 1,37 \\
\hline 7 & 0 & 2,93 & 2,93 \\
\hline 8 & 15 & 12,07 & 2,93 \\
\hline 9 & 15 & 13,49 & 1,51 \\
\hline 10 & 0 & $-1,37$ & 1,37 \\
\hline \multicolumn{4}{|c|}{ MAE } \\
\hline
\end{tabular}

Berdasarkan Tabel V didapatkan error berdasarkan perhitungan $M A E$ untuk koordinat $y$ sebesar $2,33 \mathrm{~cm}$, di mana error terbesar yaitu $5,81 \mathrm{~cm}$ dan terkecil $0,05 \mathrm{~cm}$.
TABEL VI

PERBANDINGAN KOORDINAT ASLI DAN PREDIKSI KOORDINAT Z

\begin{tabular}{|c|c|c|c|}
\hline No & Asli & Prediksi & Error $(\mathbf{c m})$ \\
\hline 1 & 0 & $-0,30$ & 0,30 \\
\hline 2 & 0 & 0,14 & 0,14 \\
\hline 3 & 0 & 0,16 & 0,16 \\
\hline 4 & 30 & 30,00 & 0,00 \\
\hline 5 & 0 & $-0,08$ & 0,08 \\
\hline 6 & 0 & $-0,07$ & 0,07 \\
\hline 7 & 15 & 14,85 & 0,15 \\
\hline 8 & 0 & 0,15 & 0,15 \\
\hline 9 & 15 & 15,08 & 0,08 \\
\hline 10 & 15 & 15,07 & 0,07 \\
\hline \multicolumn{4}{|c|}{ MAE } \\
\hline
\end{tabular}

Berdasarkan Tabel VI didapatkan error berdasarkan perhitungan $M A E$ untuk koordinat $z$ sebesar $0,12 \mathrm{~cm}$, di mana error paling besar yaitu $0,30 \mathrm{~cm}$ dan paling kecil 0,00 $\mathrm{cm}$. Adapun grafik beda error dari kernel dapat dilihat pada Gambar 12.

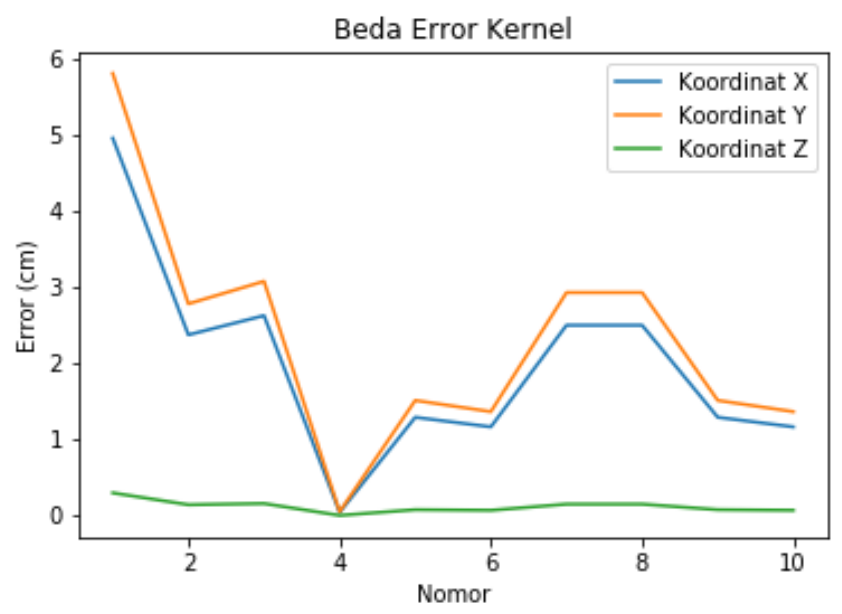

Gambar 12. Beda Error Koordinat $x, y, z$

Gambar 12 merupakan grafik beda error kernel di mana koordinat $x$ ditandai dengan warna biru, koordinat $y$ dengan warna jingga, dan koordinat $z$ dengan warna hijau. Dari grafik tersebut dapat diketahui bahwa tingkat error untuk koordinat $x$ dan $y$ hampir sama. Hal ini disebabkan karena terdapat perbedaan sudut pandang dari kedua kamera yang dibuat menyerupai cara kerja dari mata manusia terhadap koordinat $x$ dan $y$. Sedangkan error dari koordinat $z$ cenderung stabil karena tinggi dari kedua kamera smartphone yang digunakan relatif sama. Perhitungan error tersebut didasarkan pada perhitungan $M A E$ dengan rumus:

$$
M A E=\frac{\sum_{I=O}^{n}|X i|}{n}
$$

Adapun hasil perhitungan $M A E$ tertera pada Tabel VII.

TABEL VII

AKURASI MAE

\begin{tabular}{|c|c|c|}
\hline Koordinat $\boldsymbol{x}$ & Koordinat $\boldsymbol{y}$ & Koordinat $\boldsymbol{z}$ \\
\hline 1,99 & 2,33 & 0,12 \\
\hline
\end{tabular}




\section{B. Pengujian Estimasi Posisi}

Pengujian estimasi posisi dilakukan menggunakan data uji berdasarkan piksel 2D dari citra wajah yang berupa video. Data uji tersebut diperoleh berdasarkan koordinat tengah pada bounding box hasil pendeteksian wajah untuk kasus satu orang. Tabel VIII merupakan hasil pengujian estimasi posisi satu orang berdasarkan tangkapan 10 frame.

TABEL VIII

PERBANDINGAN JARAK ASLI DAN PREDIKSI

\begin{tabular}{|c|c|c|}
\hline $\begin{array}{c}\text { Jarak Asli } \\
(\mathbf{c m})\end{array}$ & Jarak Prediksi (cm) & $\begin{array}{c}\text { Beda Error } \\
(\mathbf{c m})\end{array}$ \\
\hline 2 & 17,84 & 15,84 \\
\hline 7 & 20,16 & 13,16 \\
\hline 12 & 22,6 & 10,6 \\
\hline 17 & 26,53 & 9,53 \\
\hline 22 & 28,05 & 6,05 \\
\hline 28 & 33,22 & 5,22 \\
\hline 33 & 37,18 & 4,18 \\
\hline \multicolumn{2}{|c|}{ Rata-rata Error $(\mathbf{c m})$} & $\mathbf{9 , 2 3}$ \\
\hline
\end{tabular}

Berdasarkan pengujian akurasi estimasi posisi yang dilakukan menghasilkan rata-rata error sebesar $9,23 \mathrm{~cm}$. Dari hasil estimasi posisi tersebut maka dapat diketahui lokasi wajah yang terdeteksi. Pengukuran jarak tersebut dilakukan berdasarkan jarak wajah dengan alat peraga yang digunakan sebagai titik referensi. Pengukuran tersebut dilakukan dengan perhitungan Euclidean sederhana.

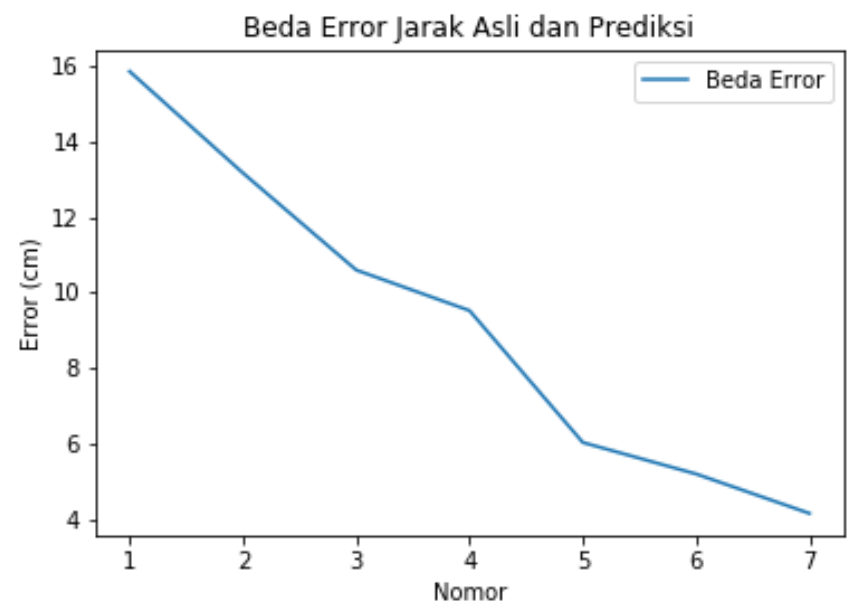

Gambar 13. Beda Error Jarak Asli dan Prediksi

Berdasarkan Gambar 13 diketahui bahwa semakin jauh jarak antara lokasi wajah dengan alat peraga, maka tingkat error akan semakin kecil yang ditandai dengan grafik menurun. Besar error dihitung menggunakan persamaan berikut,

$$
\begin{aligned}
& R_{\varepsilon}=\sum_{i=0}^{n} \frac{\left|r^{\prime}{ }_{i}-r_{i}\right|}{n} \\
& r^{\prime}=\sqrt{x_{\mu}^{2}+y_{\mu}^{2}+z_{\mu}^{2}}
\end{aligned}
$$

Di mana $R_{\varepsilon}$ adalah jarak error rata-rata, $\mathrm{n}$ adalah jumlah sampel pengujian dengan jarak asli yang berbeda-beda antara wajah ke titik $O$ pada alat peraga sebagai titik referensi, $r_{i}$ adalah jarak asli wajah ke titik O pada kasus ke$\mathrm{i}, r_{i}^{\prime}$ adalah jarak prediksi antara wajah ke titik O.

Karena disetiap kasus pengujian menggunakan video yang durasinya berbeda-beda, maka nilai $r^{\prime}$ pun merupakan ratarata dari jarak prediksi yang didapat di setiap frame-nya. $r^{\prime}$ dihitung menggunakan jarak Euclidean sederhana di atas dengan masing-masing komponen $x, y, z$ merupakan ratarata dari nilai seluruh frame.

\section{Pengujian Pengenalan Wajah}

Metode pengenalan wajah yang digunakan yaitu $L B P H$ Face Recognizer. Sedangkan metode yang digunakan untuk pendeteksian wajah yaitu Haar Cascade Classifier. Contoh akurasi pengenalan wajah dapat dilihat pada Tabel IX.

TABEL IX

CONTOH AKURASI PENGENALAN WAJAH

\begin{tabular}{|c|c|}
\hline Nama Asli & Presentase Keberhasilan \\
\hline Putra & $100 \%$ \\
\hline Akmal & $90 \%$ \\
\hline Akrom & $100 \%$ \\
\hline Akurasi & $\mathbf{9 7 \%}$ \\
\hline
\end{tabular}

Berdasarkan Tabel IX didapatkan akurasi pengenalan wajah sebesar 97\%. Akurasi tersebut diperoleh dari hasil pengenalan wajah pada tiga video yang berbeda untuk tiaptiap orang dalam keadaan diam dan diambil sebanyak 10 frame pada video. Pengenalan wajah semakin buruk apabila data latih yang digunakan memiliki banyak kesamaan antara satu dengan orang yang lain, kemudian pencahayaan yang buruk, serta sudut dan jarak yang tidak tepat dapat membuat wajah menjadi sulit untuk dikenali. Perhitungan akurasi pengenalan wajah dihitung menggunakan persamaan berikut,

$$
\text { Akurasi }=\frac{\text { Jumlah Presentase Keberhasilan }}{\text { Total Percobaan }} \times 100 \%
$$

\section{Pengujian Clustering}

Pengujian clustering dilakukan dengan data beberapa video yang berisi satu orang, dua orang, dan tiga orang. Hasil pengujian clustering untuk satu orang dapat dilihat pada Tabel X, Tabel XI, dan Tabel XII.

TABEL X

Pengujian Clustering Kasus 1 ORAng Video 1

\begin{tabular}{|c|c|c|}
\hline \multirow{2}{*}{ No } & \multicolumn{2}{|c|}{ 1 Cluster } \\
\cline { 2 - 3 } & Kamera 1 & Kamera 2 \\
\hline 1 & Putra & Putra \\
\hline 2 & Putra & Putra \\
\hline 3 & Putra & Putra \\
\hline 4 & Putra & Putra \\
\hline 5 & Putra & Putra \\
\hline 6 & Putra & Putra \\
\hline 7 & Putra & Putra \\
\hline 8 & Putra & Putra \\
\hline 9 & Putra & Putra \\
\hline 10 & Putra & Putra \\
\hline Modus & Putra & Benar \\
\hline Hasil & & \\
\hline
\end{tabular}


Dari Tabel X didapatkan nama yang paling sering keluar pada 10 frame untuk kamera 1 dan 2 yaitu Putra berdasarkan 10 kali program melakukan prediksi nama dengan benar. Tabel XI merupakan hasil pengujian kasus 1 orang video 2 .

TABEL XI

Pengujian Clustering Kasus 1 Orang Video 2

\begin{tabular}{|c|c|c|}
\hline \multirow{2}{*}{ No } & \multicolumn{2}{|c|}{ 1 Cluster } \\
\cline { 2 - 3 } & Kamera 1 & Kamera 2 \\
\hline 1 & Akmal & Akmal \\
\hline 2 & Akmal & Akmal \\
\hline 3 & Akmal & Akmal \\
\hline 4 & Akmal & Akmal \\
\hline 5 & - & Akmal \\
\hline 6 & - & Akmal \\
\hline 7 & - & Akmal \\
\hline 8 & - & Akmal \\
\hline 9 & - & Akmal \\
\hline 10 & - & Akmal \\
\hline Modus & Akmal & Benar \\
\hline Hasil & \multicolumn{2}{c}{} \\
\hline
\end{tabular}

Dari Tabel XI didapatkan nama yang paling sering keluar untuk kamera 1 dan 2 yaitu Akmal. Pada pengujian yang dilakukan, kamera 1 hanya mengenali 4 frame dari total 10 frame. Sedangkan untuk kamera 2, program dapat mengenali Akmal berdasarkan total 10 frame. Tabel XII merupakan hasil pengujian kasus 1 orang video 3 .

TABEL XII

Pengujian CLUSTERING Kasus 1 ORANG Video 3

\begin{tabular}{|c|c|c|}
\hline \multirow{2}{*}{ No } & \multicolumn{2}{|c|}{ 1 Cluster } \\
\cline { 2 - 3 } & Kamera 1 & Kamera 2 \\
\hline 1 & Akrom & Akrom \\
\hline 2 & Akrom & Akrom \\
\hline 3 & Akrom & Akrom \\
\hline 4 & Akrom & Akrom \\
\hline 5 & Akrom & Akrom \\
\hline 6 & Akrom & Akrom \\
\hline 7 & Akrom & Akrom \\
\hline 8 & Akrom & Akrom \\
\hline 9 & Akrom & Akrom \\
\hline 10 & Akrom & Akrom \\
\hline Modus & Akrom \\
\hline Hasil & \multicolumn{2}{c}{ Benar } \\
\hline
\end{tabular}

Dari Tabel XII didapatkan nama yang paling sering keluar untuk kamera 1 dan 2 yaitu Akrom berdasarkan 10 kali melakukan prediksi nama dengan benar pada 10 frame.

Pada pengujian kasus 1 orang untuk 3 video yang berbeda, didapatkan hasil pengenalan wajah yang benar sepenuhnya untuk tiap-tiap orang. Dengan hasil tersebut membuat pengujian clustering dapat dilakukan dengan baik dan tepat karena hanya membuat 1 cluster. Estimasi posisi diperoleh dari penggabungan hasil clustering pada kamera 1 dan 2 untuk wajah yang terdeteksi, sehingga mendapatkan data koordinat 2D pada gambar $(x 1, y 1, x 2, y 2)$. Berikut salah satu contoh gambar plotting pada 3D Scatter Plot untuk kasus 1 orang.

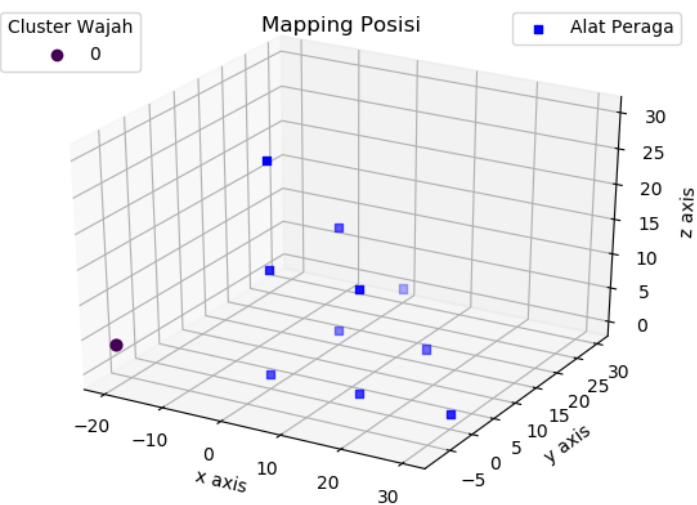

Gambar 14. 3D Scatter Plot Kasus 1 orang

Gambar 14 merupakan contoh mapping posisi berdasarkan estimasi yang telah dilakukan untuk clustering kasus satu orang. Isi dari mapping tersebut meliputi cluster wajah yang berjumlah satu yang ditandai dengan ' $o$ ' marker berwarna merah, sedangkan ' $s$ ' marker berwarna biru menandakan 10 titik dari alat peraga yang digunakan. Lokasi orang tersebut didapatkan setelah dibuat mean dari pergerakkan yang dilakukan sehingga menghasilkan satu titik koordinat 3D untuk orang tersebut. Pengujian clustering yang kedua dilakukan dengan video yang berisi 2 orang. Hasil pengujiannya dapat dilihat pada Tabel XIII, Tabel XIV, dan Tabel XV.

TABEL XIII

Pengujian Clustering Kasus 2 ORANG Video 1

\begin{tabular}{|c|c|c|c|c|}
\hline \multirow{2}{*}{ No } & \multicolumn{2}{|c|}{ Kamera 1 } & \multicolumn{2}{c|}{ Kamera 2 } \\
\cline { 2 - 5 } & Cluster 0 & Cluster 1 & Cluster 0 & Cluster 1 \\
\hline 1 & Akrom & Putra & Akrom & Putra \\
\hline 2 & Putra & Putra & Putra & Putra \\
\hline 3 & Akrom & Putra & Akrom & Putra \\
\hline 4 & Akrom & Akmal & Putra & Putra \\
\hline 5 & Akrom & Putra & Putra & Putra \\
\hline 6 & Akrom & Akmal & Akrom & Putra \\
\hline 7 & Akrom & Akmal & Akrom & Putra \\
\hline 8 & Akrom & Putra & Putra & Putra \\
\hline 9 & Akrom & Putra & Akrom & Putra \\
\hline 10 & Akrom & Putra & Akrom & Putra \\
\hline Modus & Akrom & Putra & Akrom & Putra \\
\hline Hasil & \multicolumn{5}{|c}{ Benar } \\
\hline
\end{tabular}

Tabel XIII merupakan hasil clustering dua orang pada video 1 di mana modus pada kamera 1 untuk cluster 0 adalah Akrom dengan 9 kali prediksi nama benar 1 salah dan cluster 1 adalah Putra dengan 7 kali prediksi nama benar 3 salah. Sementara itu, modus pada kamera 2 untuk cluster 0 adalah Akrom dengan 6 kali prediksi nama benar 4 salah dan cluster 1 adalah Putra dengan 10 kali prediksi 
nama benar. Tabel XIV merupakan hasil clustering dua orang untuk video 2 .

TABEL XIV

PENGUJian CLUSTERING KASUS 2 ORANG VIDEO 2

\begin{tabular}{|c|c|c|c|c|}
\hline \multirow{2}{*}{ No } & \multicolumn{2}{|c|}{ Kamera 1 } & \multicolumn{2}{c|}{ Kamera 2 } \\
\cline { 2 - 5 } & Cluster 0 & Cluster 1 & Cluster 0 & Cluster 1 \\
\hline 1 & Putra & Putra & Akmal & Putra \\
\hline 2 & Akmal & Putra & Akmal & Putra \\
\hline 3 & Akmal & Putra & Akmal & Putra \\
\hline 4 & Akmal & Putra & Akmal & Putra \\
\hline 5 & Akmal & Putra & Akmal & Putra \\
\hline 6 & Akmal & Putra & Akmal & Putra \\
\hline 7 & Akmal & Putra & Akmal & Putra \\
\hline 8 & Akmal & Putra & Akmal & Putra \\
\hline 9 & Akmal & Putra & Akmal & Putra \\
\hline 10 & Akmal & Putra & Putra & Putra \\
\hline Modus & Akmal & Putra & Akmal & Putra \\
\hline Hasil & \multicolumn{4}{|c|}{ Benar } \\
\hline \multicolumn{7}{|c|}{}
\end{tabular}

Berdasarkan Tabel XIV didapatkan modus pada kamera 1 dan kamera 2 untuk cluster 0 adalah Akmal dengan 9 kali prediksi nama benar dari 10 frame dan cluster 1 adalah Putra dengan 10 kali benar dalam melakukan prediksi nama. Tabel XV merupakan hasil clustering dua orang untuk video 3.

TABEL XV

PENGUJiAn CLUSTERING KASUS 2 ORANG VIDEO 3

\begin{tabular}{|c|c|c|c|c|}
\hline \multirow{2}{*}{ No } & \multicolumn{2}{|c|}{ Kamera 1 } & \multicolumn{2}{c|}{ Kamera 2 } \\
\cline { 2 - 5 } & Cluster 0 & Cluster 1 & Cluster 0 & Cluster 1 \\
\hline 1 & Akrom & Akmal & Akrom & Akmal \\
\hline 2 & Akrom & Akmal & Akrom & Akmal \\
\hline 3 & Akrom & Akmal & Akrom & Akmal \\
\hline 4 & Akrom & Akmal & Akrom & Akmal \\
\hline 5 & Akrom & Akmal & Akrom & Akmal \\
\hline 6 & Akrom & Akmal & Akrom & Akmal \\
\hline 7 & Akrom & Akmal & Akrom & Akmal \\
\hline 8 & Akrom & Akmal & Akrom & Akmal \\
\hline 9 & Akrom & Akmal & Akrom & Akmal \\
\hline 10 & Akrom & Akmal & Akrom & Akmal \\
\hline Modus & Akrom & Akmal & Akrom & Akmal \\
\hline Hasil & \multicolumn{4}{|c|}{ Benar } \\
\hline \multicolumn{4}{|c}{} \\
\hline
\end{tabular}

Berdasarkan Tabel XV didapatkan modus pada kamera 1 dan 2 untuk cluster 0 adalah Akrom dengan total 10 kali benar dalam melakukan prediksi nama, kemudian modus pada cluster 1 adalah Akmal yang juga memiliki total 10 kali benar dalam memprediksi nama.

Berdasarkan hasil pengujian kasus 2 orang dengan 3 video yang berbeda didapatkan hasil clustering yang baik karena dapat membedakan dua wajah dengan warna yang berbeda untuk menunjukkan bahwa ada 2 cluster atau 2 wajah. Pada pengujian kasus 2 orang, program pengenalan wajah tidak sepenuhnya memprediksi nama dengan benar. Walaupun begitu, dengan fungsi modus ini dapat tetap memberikan hasil nama yang benar berdasarkan pada perhitungan nama yang paling banyak keluar dalam 10 frame. Berikut salah satu contoh mapping pada $3 D$ Scatter Plot untuk kasus dua orang.

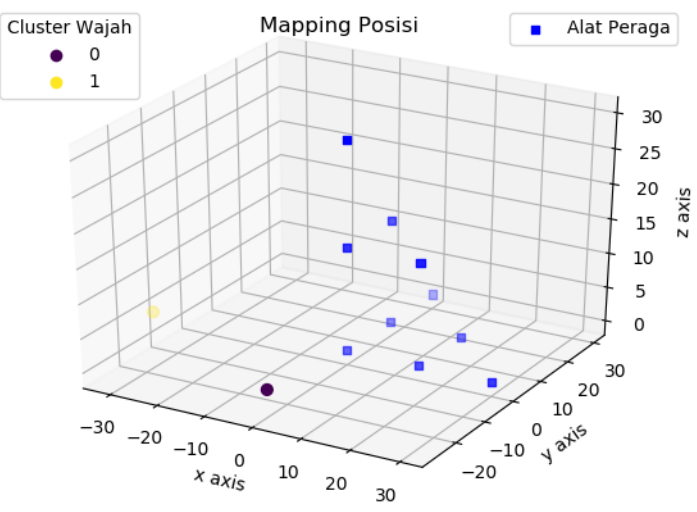

Gambar 15. 3D Scatter Plot Kasus 2 Orang

Gambar 15 merupakan contoh mapping posisi dalam bentuk koordinat 3D berdasarkan estimasi yang telah dilakukan untuk clustering kasus dua orang. Isi dari mapping tersebut meliputi dua cluster wajah yang ditandai dengan 'o' marker berwarna kuning dan merah, sedangkan 's' marker berwarna biru menandakan 10 titik dari alat peraga yang digunakan. Lokasi tersebut didapatkan setelah dibuat mean dari pergerakkan yang dilakukan terhadap wajah sehingga menghasilkan satu titik koordinat 3D untuk tiap-tiap orang tersebut. Pengujian clustering yang ketiga dilakukan dengan video yang berisi tiga orang. Tabel XVI merupakan clustering untuk kasus 3 orang.

TABEL XVI

PENGUJian CLUSTERING Kasus 3 ORANG

\begin{tabular}{|c|c|c|c|c|c|c|}
\hline \multirow{3}{*}{ No } & \multicolumn{3}{|c|}{ Kamera 1 } & \multicolumn{3}{c|}{ Kamera 2 } \\
\cline { 2 - 7 } & \multicolumn{3}{|c|}{ Cluster } & \multicolumn{3}{c|}{ Cluster } \\
\cline { 2 - 7 } & 0 & 1 & 2 & 0 & 1 & 2 \\
\hline 1 & Putra & Akrom & Akmal & Putra & Akrom & Akmal \\
\hline 2 & Putra & Akrom & Akmal & Putra & Akrom & Akmal \\
\hline 3 & Akrom & Akrom & Akmal & Putra & Akrom & Akmal \\
\hline 4 & Putra & Akrom & - & Putra & Akrom & Akmal \\
\hline 5 & Akrom & Akrom & - & Putra & Akrom & Akmal \\
\hline 6 & Putra & Akrom & - & Putra & Akrom & Akmal \\
\hline 7 & Akmal & Akrom & - & Putra & Akrom & Akmal \\
\hline 8 & Putra & Akrom & - & Putra & Akrom & Akmal \\
\hline 9 & Akrom & Akrom & - & Putra & Akrom & Akmal \\
\hline 10 & Putra & Akrom & - & Putra & Akrom & Akmal \\
\hline Modus & Putra & Akrom & Akmal & Putra & Akrom & Akmal \\
\hline Hasil & \multicolumn{7}{c}{ Benar } \\
\hline
\end{tabular}

Dari Tabel XVI didapatkan modus pada kamera 1 untuk cluster 0 adalah Putra dengan 6 kali prediksi nama benar dan 4 kali salah, kemudian untuk cluster 1 adalah Akrom dengan 10 kali benar, lalu untuk cluster 2 adalah Akmal dengan total pengenalan berjumlah 3 kali berdasarkan 10 frame dan benar semua. Sedangkan pada kamera 2 untuk 
cluster 0 adalah Putra, cluster 1 adalah Akrom, dan cluster 2 adalah Akmal dengan 10 kali prediksi nama benar untuk tiap-tiap orang. Berikut salah satu contoh mapping pada $3 D$ Scatter Plot untuk kasus tiga orang.

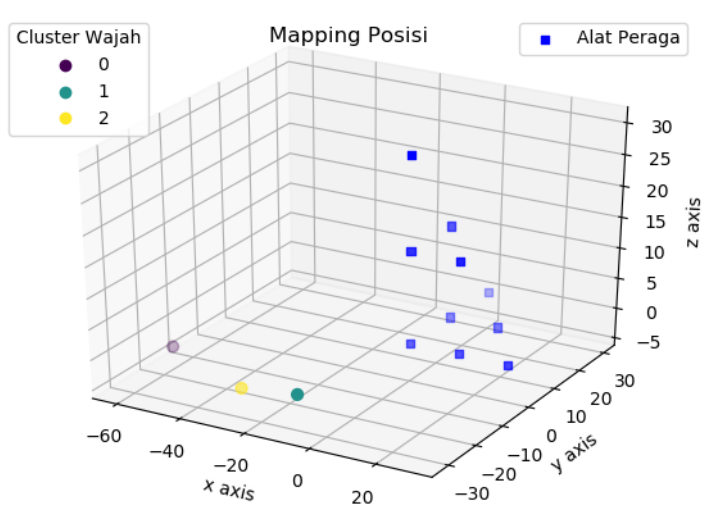

Gambar 16. 3D Scatter Plot Kasus 3 Orang

Gambar 16 merupakan contoh mapping posisi dalam bentuk koordinat 3D berdasarkan estimasi yang telah dilakukan untuk clustering kasus tiga orang. Isi dari mapping tersebut meliputi tiga cluster wajah yang ditandai dengan 'o' marker berwarna kuning, hijau dan merah, sedangkan 's' marker berwarna biru menandakan 10 titik dari alat peraga yang digunakan. Lokasi orang tersebut didapatkan setelah dibuat mean dari pergerakkan wajah yang dilakukan sehingga menghasilkan satu titik koordinat 3D untuk tiap-tiap orang. Tabel XVII adalah rekapitulasi hasil pengujian clustering.

TABEL XVII

ReKapitulasi Hasil PENGUJian CLUSTERING

\begin{tabular}{|c|c|c|c|c|c|c|}
\hline No & $\begin{array}{c}\text { Kasus } \\
\mathbf{1}\end{array}$ & Hasil & $\begin{array}{c}\text { Kasus } \\
\mathbf{2}\end{array}$ & Hasil & $\begin{array}{c}\text { Kasus } \\
\mathbf{3}\end{array}$ & Hasil \\
\hline 1 & Putra & Benar & Akrom & Benar & Putra & Benar \\
\hline 2 & Akmal & Benar & Putra & Benar & Akmal & Benar \\
\hline 3 & Akrom & Benar & Akmal & Benar & Akrom & Benar \\
\hline 4 & - & - & Putra & Benar & - & - \\
\hline 5 & - & - & Akrom & Benar & - & - \\
\hline 6 & - & - & Akmal & Benar & - & - \\
\hline Hasil & \multicolumn{7}{|c|}{ 3 Benar Benar } & \multicolumn{3}{|c|}{ 3 Benar } \\
\hline Akurasi & \multicolumn{7}{|c|}{ 6 Benar } \\
\hline
\end{tabular}

Berdasarkan pengujian yang telah dilakukan, maka total akurasi tracking berbasis clustering sebesar $100 \%$ berdasarkan 12 kali benar dari total 12 percobaan.

\section{E. Pengujian Sistem}

Sistem ini menggunakan user interface berupa aplikasi desktop yang dibangun dengan Tkinter GUI karena sistem ini dibuat dengan bahasa pemrograman Python sehingga lebih mudah untuk diintegrasikan di mana proses-prosesnya dibuat sederhana agar mudah dipahami oleh user dan dapat digunakan sesuai kebutuhan. Pengujian ini didasarkan pada pengujian fungsional dengan menguji beberapa parameter fungsional yang telah disusun seperti pada Tabel XVIII.

TABEL XVIII

PENGUJIAN Fungsional

\begin{tabular}{|c|c|c|c|c|c|c|c|c|c|c|}
\hline \multirow{2}{*}{$\begin{array}{l}\text { Kebutuhan } \\
\text { Fungsional } \\
\end{array}$} & \multicolumn{10}{|c|}{ Percobaan } \\
\hline & 1 & 2 & 3 & 4 & 5 & 6 & 7 & 8 & 9 & 10 \\
\hline $\begin{array}{l}\text { Sistem dapat } \\
\text { menampilkan } \\
\text { panduan }\end{array}$ & $\mathrm{v}$ & $\mathrm{v}$ & $\mathrm{v}$ & $\mathrm{V}$ & $\mathrm{v}$ & $\mathrm{V}$ & $\mathrm{v}$ & $\mathrm{v}$ & $\mathrm{v}$ & $\mathrm{v}$ \\
\hline $\begin{array}{l}\text { Sistem dapat } \\
\text { mengisikan ID } \\
\text { dan Nama } \\
\text { untuk } \\
\text { registrasi } \\
\text { wajah baru }\end{array}$ & $\mathrm{V}$ & $\mathrm{x}$ & $\mathrm{V}$ & $\mathrm{V}$ & $\mathrm{V}$ & $\mathrm{v}$ & $\mathrm{v}$ & $\mathrm{V}$ & $\mathrm{V}$ & $\mathrm{v}$ \\
\hline $\begin{array}{l}\text { Sistem dapat } \\
\text { membuat } \\
\text { dataset }\end{array}$ & $\mathrm{V}$ & $\mathrm{V}$ & $\mathrm{v}$ & $\mathrm{V}$ & $\mathrm{V}$ & $\mathrm{x}$ & $\mathrm{v}$ & $\mathrm{v}$ & $\mathrm{v}$ & $\mathrm{v}$ \\
\hline $\begin{array}{l}\text { Sistem dapat } \\
\text { melakukan } \\
\text { training } \\
\text { berdasarkan } \\
\text { dataset }\end{array}$ & $\mathrm{V}$ & $\mathrm{v}$ & $\mathrm{V}$ & $\mathrm{V}$ & $\mathrm{V}$ & $\mathrm{V}$ & $\mathrm{V}$ & $\mathrm{v}$ & $\mathrm{v}$ & $\mathrm{v}$ \\
\hline $\begin{array}{l}\text { Sistem dapat } \\
\text { melakukan } \\
\text { presensi dan } \\
\text { menampilkan } \\
\text { hasil estimasi } \\
\text { posisi serta } \\
\text { clustering } \\
\text { pada } 3 D \\
\text { scatter plot }\end{array}$ & $\mathrm{V}$ & $\mathrm{x}$ & $\mathrm{V}$ & $\mathrm{V}$ & $\mathrm{V}$ & $\mathrm{V}$ & $\mathrm{V}$ & $\mathrm{v}$ & $\mathrm{v}$ & $\mathrm{v}$ \\
\hline $\begin{array}{l}\text { Sistem dapat } \\
\text { melakukan } \\
\text { penyimpanan } \\
\text { dan } \\
\text { menampilkan } \\
\text { data presensi }\end{array}$ & $\mathrm{V}$ & $\mathrm{x}$ & $\mathrm{v}$ & $\mathrm{v}$ & $\mathrm{v}$ & $\mathrm{v}$ & $\mathrm{V}$ & $\mathrm{v}$ & $\mathrm{v}$ & $\mathrm{v}$ \\
\hline
\end{tabular}

Berdasarkan pengujian yang telah dilakukan secara fungsional terhadap sistem, didapatkan tingkat akurasi sebesar 93\% berdasarkan empat kali salah dari 60 kali percobaan untuk semua kebutuhan fungsional.

\section{KESIMPULAN}

Berdasarkan hasil penelitian yang telah dilakukan, kesimpulannya yaitu algoritma LASSO dapat digunakan untuk pembuatan kernel agar dapat memprediksi koordinat nyata berdasarkan koordinat gambar. Dari hasil kernel tersebut akan dilakukan estimasi posisi berdasarkan pengukuran jarak dari objek target dengan objek referensi. Berdasarkan pengujian estimasi posisi yang telah dilakukan, jarak antara objek target yang berupa wajah dan objek referensi yang berupa alat peraga berbentuk koordinat kartesian 3D dapat dihitung dengan perhitungan Euclidean. Berdasarkan hasil perhitungan, semakin jauh jarak antara wajah dan alat peraga maka tingkat error semakin kecil. 
Selain itu, pengujian untuk tracking berbasis clustering agar dapat melacak posisi wajah dapat dilakukan dengan baik oleh algoritma K-Means. Clustering ini dilakukan berdasarkan hasil prediksi wajah yang didapatkan dari proses pengenalan wajah. Oleh karena itu, hasil clustering sangat dipengaruhi oleh hasil prediksi wajah. Apabila wajah dapat dideteksi dan dikenali dengan baik, maka proses tracking berbasis clustering dapat dilakukan dengan baik juga.

Penelitian ini berfokus pada model untuk estimasi posisi dan tracking berbasis clustering menggunakan dataset dari tiga orang. Model ini dapat digunakan sebagai penunjang pada sistem presensi untuk mendapatkan lokasi dari orang dalam bentuk koordinat 3D. Hal ini dimaksudkan agar sistem dapat mengenali wajah seseorang walaupun tidak secara langsung melakukan proses presensi dengan cara berdiri di depan sensor kamera. Berdasarkan hasil pengujian yang dilakukan dapat diasumsikan untuk empat atau lebih orang bisa dilakukan dengan baik.

\section{SARAN}

Adapun beberapa saran pada penelitian ini untuk dikembangkan lagi di penelitian selanjutnya adalah mengenai pencahayaan ketika melakukan pengenalan wajah perlu diperhatikan dan diadakan penelitian lebih lanjut mengenai batasan pencahayaan yang baik, kemudian untuk penelitian selanjutnya diharapkan menerapkan metode alternatif lain sebagai pembanding, dan sebaiknya menggunakan kamera eksternal khusus agar menghasilkan gambar yang lebih baik serta hardware yang mumpuni untuk implementasi secara realtime serta menggunakan dataset yang lebih banyak agar hasil pengenalan dapat prima.

\section{DAFTAR PUSTAKA}

[1] E. B. Setiawan and B. Kurniawan, "Perancangan Sistem Absensi Kehadiran Perkuliahan dengan Menggunakan Radio Frequency Identification (RFId)," CoreIT, vol. 1, no. 2, pp. 44-49, 2015.

[2] R. Rian, C. Putra, and F. P. Juniawan, "Penerapan Algoritma Fisherfaces Untuk Pengenalan Wajah Pada Sistem Kehadiran Mahasiswa Berbasis Android," J. Telemat., vol. 10, no. 1, pp. 132 146, 2017.

[3] C. Suhery and I. Ruslianto, "Identifikasi Wajah Manusia untuk Sistem Monitoring Kehadiran Perkuliahan menggunakan Ekstraksi Fitur Principal Component Analysis ( PCA ),"J. Edukasi dan Penelit. Inform., vol. 3, no. 1, pp. 9-15, 2017.

[4] D. Rusjdi, C. J. Kusumo, and A. Yudha, "Perancangan Simulasi Penentuan Koordinat Obyek Di Dalam Ruang Menggunakan Kamera Digital," PETIR, vol. 5, no. 2, pp. 76-185, 2012.

[5] H. Afrisal, I. Soesanti, and A. I. Cahyadi, "Estimasi Posisi Dengan Menggunakan Kamera Monokular," TRANSMISI, vol. 21, no. 1, pp. $1-9,2019$.

[6] M. A. Firmansyah and I. Supriana, "Multiple Object Tracking dan Estimasi Posisi untuk Menunjang Sistem Keamanan Rumah," in Konferensi Nasional Informatika (KNIF), 2015, pp. 1-6.

[7] I. Maliki, "3 Dimensi," in Grafika Komputer, Bandung: Universitas Komputer Indonesia, 2010, pp. 44-48.

[8] R. Munir, "Pembentukan Citra," in Pengolahan Citra Digital, Bandung: Informatika, 2004, pp. 15-28.

[9] S. Monika, A. Rakhman, and Lindawati, "Pengaman Rumah dengan Sistem Face Recognition Secara Real Time Menggunakan Metode Principal Component Analysis," ISBN 978-602-1180-50-1, pp. 395401, 2017.

[10] A. Ahmad. (2017) Mengenal Artificial Intelligence , Machine Learning, Neural Network, dan Deep Learning. [Online]. Tersedia: https://www.researchgate.net/publication/320395378_Mengenal_Art ificial_Intelligence_Machine_Learning_Neural_Network_dan_Deep Learning

[11] F. K. H. Prabowo, Y. Wilandari, and A. Rusgiyono, "Pemodelan Pertumbuhan Ekonomi Jawa Tengah Menggunakan Pendekatan Least Absolute Shrinkage and Selection Operator (LASSO)," GAUSSIAN, vol. 4, no. 4, pp. 855-864, 2015.

[12] D. P. Prabowo, K. Latifah, and R. A. Pramunendar, "Pelacakan dan Segmentasi Objek Bergerak Menggunakan Metode K-Means Clustering Berbasis Variasi Jarak," Inform. UPGRIS, vol. 5, no. 1, pp. 111-115, 2019. 